УДК 621.362

\title{
Control Conductance of Single Walled Carbon Nanotubes Films During Synthesis
}

\author{
Yaroslav A. Bryantsev* \\ Nikolaev Institute of Inorganic Chemistry \\ Lavrentiev, 3, Novosibirsk 630090 \\ Novosibirsk State Technical University \\ Marksa, 20, Novosibirsk, 630073 \\ Russia \\ Viacheslav E. Arhipov ${ }^{\dagger}$ \\ Nikolaev Institute of Inorganic Chemistry \\ Lavrentiev, 3, Novosibirsk 630090 \\ Russia \\ Anatoly I. Romanenko ${ }^{\ddagger}$ \\ Nikolaev Institute of Inorganic Chemistry \\ Lavrentiev, 3, Novosibirsk 630090 \\ National Research Tomsk State University \\ Lenina, 36, Tomsk, 634050 \\ Russia \\ Alexander S. Berdinsky ${ }^{\S}$ \\ Novosibirsk State Technical University \\ Marksa, 20, Novosibirsk, 630073 \\ Russia \\ Alexander V. Okotrub \\ Nikolaev Institute of Inorganic Chemistry \\ Lavrentiev, 3, Novosibirsk 630090 \\ Russia
}

Received 11.10.2016, received in revised form 11.11.2017, accepted 20.02.2018

We investigated electrical conductance of single-walled carbon nanotubes (SWCNTs) films during the time of synthesis. The time dependence of conductance have been described in terms of the Shklovsky - de Gennes percolation model. Measurements of electrical conductance during the synthesis allow to control the repeatability and take samples from the desired values of electrical conductance.

Keywords: carbon nanotubes, electrical percolation.

DOI: 10.17516/1997-1397-2018-11-2-222-226.

\section{Introduction}

SWNTs have unique mechanical and electrical properties, thus are widely used [1]. There are several methods of producing CNTs: arc discharge [2], laser ablation [3] and the chemical vapor deposition [4]. The method of chemical vapor deposition is most suitable for use in the semiconductor industry due to the relatively low reaction temperature, low cost of synthesis and

\footnotetext{
*bryantsev7@mail.ru

†arhipov@niic.nsc.ru

$\ddagger$ air@niic.nsc.ru

§berdinsky.alexander@gmail.com

ฯspectrum@niic.nsc.ru

(C) Siberian Federal University. All rights reserved
} 
good repeatability. In this paper SWCNT films were produced by the catalytic disproportionation of $\mathrm{CO}$ using ferrocene as a catalyst precursor. The choice of ferrocene was made because of its low cost and low toxicity. By using resistive cell during synthesis, we can control the electrical conductance of the SWCNT films.

\section{Experimental}

Parameters of synthesis process were similar to described in [5]: 1. The reactor pressure was the atmospheric. 2. Synthesis Reactor temperature $900^{\circ} \mathrm{C}$. 3. Ferrocene vapor pressure $\left(\left(\mathrm{C}_{5} \mathrm{H}_{5}\right)_{2} \mathrm{Fe}\right) 2 \mathrm{~Pa}$. The scheme of vertical flow-type chemical reactor shown in Fig. 1a.

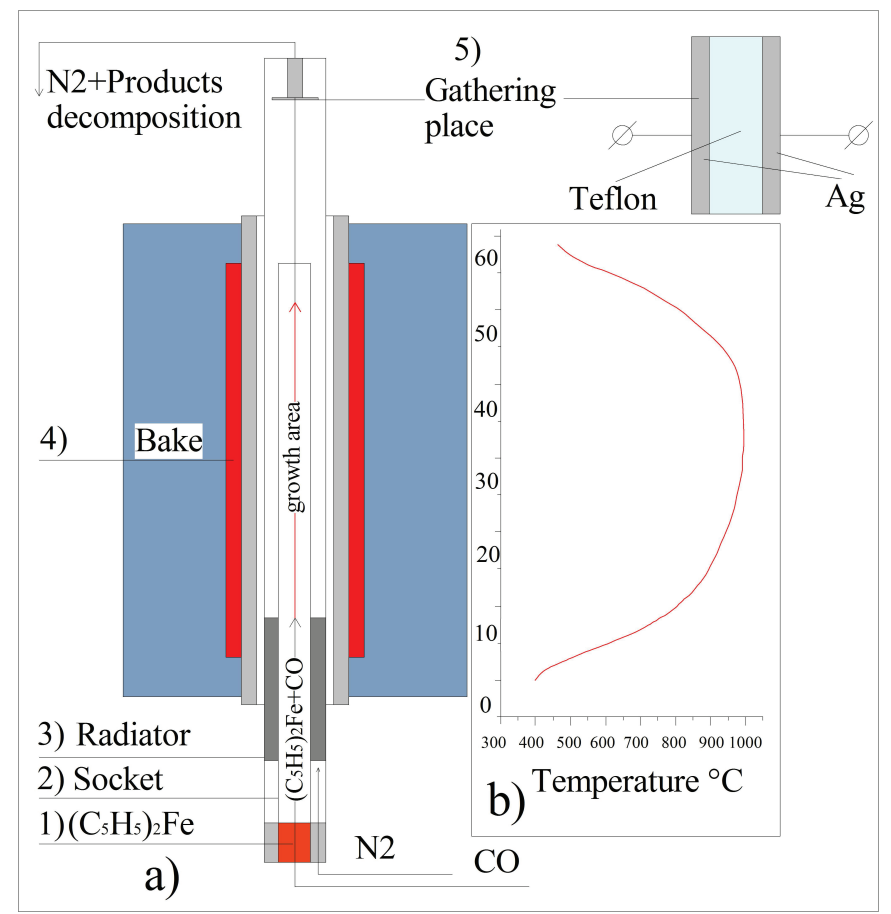

Fig. 1. The scheme (a) and the reactor temperature profile (b)

In contrast to the synthesis process described in [5], the SWNTs are collected at the top of the unit with the purposes to exclude the ingress of unstructured carbon from the reactor walls. Synthesis process of SWNT was next: 1. Reactor evacuation with a vacuum pump. 2. Purge the reaction vessel with nitrogen for $5 \mathrm{~min}$. 3. Submission of CO into the cartridge (1), where its saturate by vapor of ferrocene. The saturated gas is supplied through the pipe (2) to the high temperature zone created by the furnace (4). 4. Synthesis time controlled by a timer. A feature of the reactor design is the existence of the radiator (3) to produce sharp temperature gradient at the inlet of the reactor. Gas-vapor mixture passing through the nozzle (2) and has a temperature of $400^{\circ} \mathrm{C}$ due to the heat sink. After that gas-vapor mixture fall into the reactor region wall which have a temperature about $800^{\circ} \mathrm{C}$ (Fig. 1b). SWCNTs are deposited on the silicon substrate mounted on the carrier (5). According to a number of analyzes carried out by the authors [6] was found that the resulting film contains SWCNT diameter to $2 \mathrm{~nm}$, with about $2 / 3$ of the tubes have a semiconductor character of the conductance and the third - the metal. 
The micrographs obtained by scanning and transmission electron microscopy (SEM and TEM), are presented in Fig. 2.

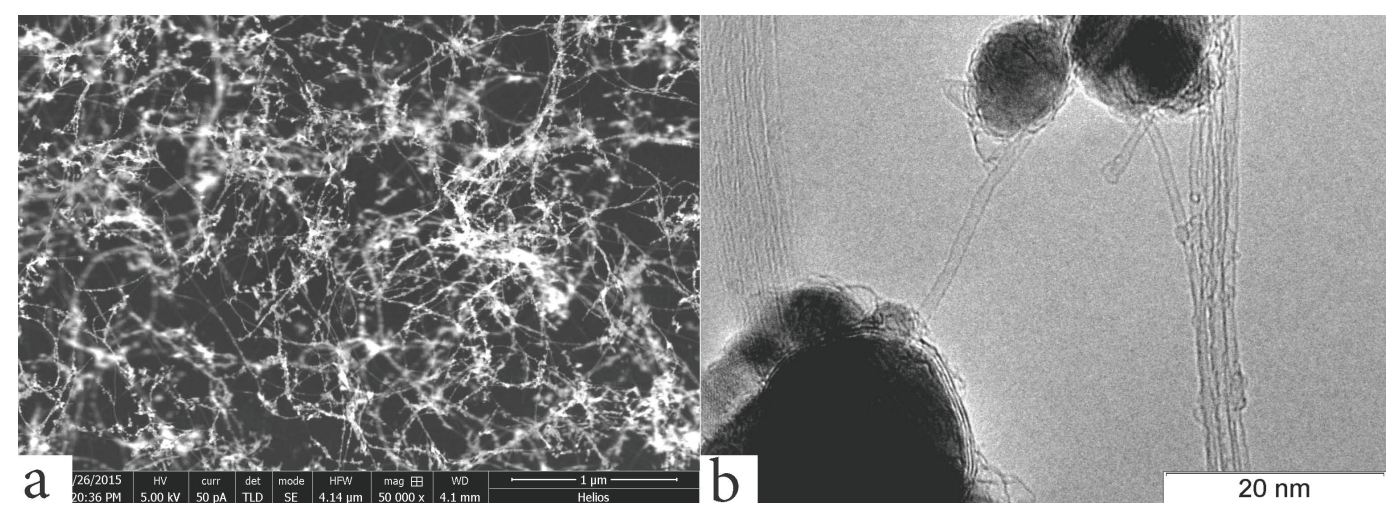

Fig. 2. SEM (a) and TEM (b) micrographs of the synthesized SWNTs

On the based of analysis SEM micrographs (Fig. 2) we found that length of the nanotubes is on average $1 \mu \mathrm{m}$. In the TEM micrograph of Fig. $2 \mathrm{~b}$ represented SWCNTs with diameters ranging from 0.82 to $1.23 \mathrm{~nm}$, which is consistent with the authors' data [6]. Resistive cell (see Fig. 1b) was used to control the synthesis process. The cell consists of a teflon plate of 3 $\mathrm{mm}$ in thickness with two silver electrodes. Deposition of SWCNT gives rise to a conductive channel whose resistance depends on the deposition time. The dependence of $G(t)$ is shown in Fig. 3 and is in good agreement with the percolation theory. Resistance measurement is carried out continuously during the synthesis by multimeter brand "Appa $107 \mathrm{n}$.

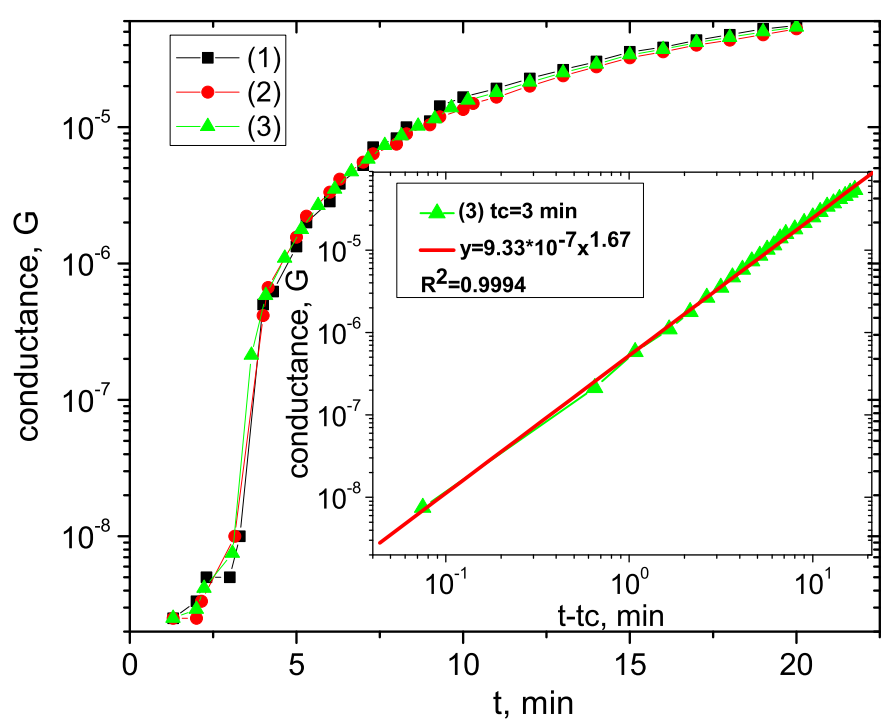

Fig. 3. The time dependence of the conductance $G(t)$ of SWCNT films in two independent experiments. The inset shown the approximation of these data in the coordinates of the percolation model 


\section{Results and discussion}

Dependence of $G(t)$ is shown in Fig. 3 and is well described by the percolation theory [7]:

$$
G(x)=G_{0} \cdot\left(x-x_{c}\right)^{k},
$$

where $x$ is the ratio of unblocked junctions to the total number of junctions, and $x_{c}$ is percolation threshold where electrical conductance vanishes, the $G_{0}$ factor of the order of the electrical conductance of the grid without the blocked sites. The value $k$ is the critical index of electrical conductance. Since in this case the number of nanotubes on substrate increases evenly with time (corresponding to an increase of the ratio of unblocked junctions to the total number of junctions), the formula (2) becomes:

$$
G(t)=G_{0} \cdot\left(t-t_{c}\right)^{k}
$$

where $t$ is the deposition time of nanotubes, and $t_{c}$ is threshold time after which begins the flow of electric current. Approximation of the curve $G(t)$ Fig. 3 in the coordinates $\log G-$ $\log \left(t-t_{c}\right)$ (straight line) gives the value of the index $k=1.67$, indicating to 3D-dimensionality of conductance grid. At low synthesis time $(t \leqslant 3 \mathrm{~min})$ we observed low conductivity (high resistance $R=1 / G$ of the film). If we take the average length of SWCNT of about $1 \mu \mathrm{m}$. with an average value of $10 \mathrm{kOhm}$ resistance according to [8], the conducting band of the SWCNTs in series (without taking into account the contact resistance) is not less than $30.000 \mathrm{kOhm}$. This number corresponding to experimental results by order of magnitude. Direct measurement of resistance of the sample during synthesis makes it possible to take samples with the desired resistance value.

\section{Conclusion}

Resistance control method was used for the synthesis of CNT films with the required resistance. The method allows to evaluate the repeatability of electrical conductance in the synthesis process, as well as it allows selected samples of different conductance, depending on the time of synthesis. The time dependences of conductance is well described by the percolation model of the grid near the percolation threshold. The critical index conductance $k=1.67$, which is typical for $3 \mathrm{D}$ systems.

\section{References}

[1] L.Xiao et al., Flexible, stretchable, transparent carbon nanotube thin film loudspeakers, Nano letters, 12(2008), 4539-4545.

[2] T.W.Ebbesen, P.M.Ajayan, Large-scale synthesis of carbon nanotubes, Nature, 358(1992), no. $6383,220-222$.

[3] T.Guo et al., Self-assembly of tubular fullerenes, The Journal of Physical Chemistry, 99(1995), no. 27, 10694-10697.

[4] P.Nikolaev et al., Gas-phase catalytic growth of single-walled carbon nanotubes from carbon monoxide, Chemical physics letters, 313(1999), no. 1, 91-97.

[5] A.G.Nasibulin, S.D.Shandakov, M.Y.Timmermans, O.V.Tolochko, E.I.Kauppinen, Synthesis of Single Walled Carbon Nanotubes by Aerosol Method, Inorganic Materials: Applied Research, 2(2011), no. 6, 589-595. 
[6] Ya.A.Bryantsev, V.E.Arhipov, A.I.Romanenko, A.S.Berdinsky, A.V.Okotrub, Control the electrical conductivity of films of single-walled carbon nanotubes in the synthesis process, The first annual Russian National Conference on Nanotechnologies, nanomaterials and microsystems technology NMST 2016, Ed. A. V. Gridchin, Sedova Zaimka, Novosibirsk, Novosibirsk Gos. Tehn. Univer., 2016, 11-15 (in Russian).

[7] A.L.Efros, Physics and geometry of disorder, Moscow, Mir, 1986.

[8] A.V.Eletskii, Transport properties of carbon nanotubes, Physics-Uspekhi, 52(2009), no. 3, 209-224.

\section{Контроль электропроводности пленок однослойных углеродных нанотрубок в процессе синтеза}

Ярослав А.Брянцев

Институт неорганической химии им. А. В. Николаева СО РАН

Лаврентьева, 3, Новосибирск, 630090

Новосибирский государственный технический университет Маркса, 20, Новосибирск, 630073

Россия

Вячеслав Е. Архипов

Институт неорганической химии им. А. В. Николаева СО РАН

Лаврентьева, 3, Новосибирск, 630090

Россия

Анатолий И. Романенко

Институт неорганической химии им. А. В. Николаева СО РАН

Лаврентьева, 3, Новосибирск, 630090

Томский государственный университет Ленина, 36, Томск, 634050

Россия

Александр С. Бердинский

Новосибирский государственный технический университет Маркса, 20, Новосибирск, 630073 Россия

Александр В. Окотруб

Институт неорганической химии им. А. В. Николаева СО РАН

Лаврентьева, 3, Новосибирск, 630090

Россия

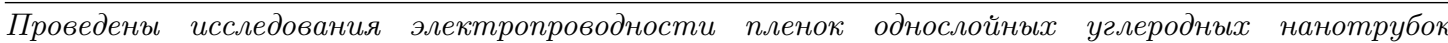
(ОУНТ) от времени синтеза. Вид зависимости кривой электропроводности от времени имеет перколяционный характер, что подтверждается линеаризацией кривой в логарифмических координатах сеточной модели перколяиии Шкловского-де ЖКена. Измерение электропроводности в процессе синтеза позволяет контролировать повторяемость результатов и отбирать образиъ с нужными значениями электропроводности.

Ключевые слова: углеродные нанотрубки, электрическая перколяция. 